\title{
Vertebrae Cervical of Egret (Egretta garzeta)
}

\author{
Nila 'Uyun Haqiqi, Pradita Icha Listya Rini, Ririn Krismiati* \\ Student of Departement Biology Education of Sunan Kalijaga State Islamic University Yogyakarta \\ J1. Marsda Adisucipto No. 1 Yogyakarta 55281, Indonesia, Tel. +62-274-540971, Fax. +62-274- 519739 \\ Email*: ririnkrismiati05@gmail.com
}

\begin{abstract}
Egret is a long-necked bird that is often found in several regions in Indonesia. Egret have different neck bone structure than the other birds. When flying position the neck can be folded to from the letter $\mathrm{S}$ and when taking food the neck can bend down unt il it reaches the ground surface. His neck is strong and cannot be broken. Egret's neck is composed of 13 vertebrae, each of which has a different structure and functions. In sections C5 to C7 have special characteristics. The sixth neck bone lengthens and the arrangement of muscle connections is elastic. To observe the cervical vertebrae in Egret done by cleaning all attached tissue then observed using a binocular stereo microscope wurh a magnification of $0.8 \mathrm{x}$. The observations show that at $\mathrm{C} 5$ it has a longer segment than the others and has posterior condyle. Then in C6 there is a pivot point that allows the Egret to pull their necks into an S shape and allows Egret to push the head forward and catch prey at high speed (Wheler, 1929)
\end{abstract}

Keywords: Vertebrae Cervical, Egret, Egretta garzetta, Pivot Point.

\section{INTRODUCTION}

Egretta garzetta is a bird from family of Ardeidae that is widespread in Asia, Africa, and Europe. In Indonesia, Egretta are found in Sumatra, Java, Kalimantan, Bali, Flores, Timor and Kepulauan Maluku (Mackinnon, 2010). Adult Egretta garzetta have a body length ranging from $10-15 \mathrm{~cm}$. When not breeding, the tip of the beak is black, the soles of the feet and toes are yellow, the legs are black and the skin on the cheecks is slightly yellowish (Mackinnon, 2010). The types of animals that become prey are mostly insects and small animals such as mollusca, crustacea, amphibi and reptilia. These birds generally forage in areas that have combined ecosystem of three types of waters namely freshwater, brackish water, and the sea such as mangroves. Egret has a nestig behavior with its own colony or other aquatic birds. The nest is built on lush trees or aquatic plants, taking food by grabbing its prey in shallow rivers or on the beach. Fly with the formation of the letter "V" when returning to the nest at night (Hancock, 1984). Egret have long neck and legs, when flying its neck, will form the letter "S".

That is what distinguishes egret with stork, whole flying, stork straighten its neck and stretch its legs. Egret when taking food, the neck craning is looking about with head and neck out stretched. Head tilting is turning both its head and its neck to one side of its body (Hancock, 1984). Egret have 13 vertebrae cervicalis that numbered from $\mathrm{C} 1$ to $\mathrm{C} 13$. The sixth vertebra (C6) in Egret's neck is longer than the others, and pivots forward around its attachment to the seventh neck vertebra (C7).

\section{MATERIAL AND METHODS}

This research use adult Egret which was obtained from rice fields. Egret soaked on formaldehyde solution $40 \%$. Observation of Egret's neck with remove skin, meat and all tissues attached in vertebrae cervical. Vertebrae cervical which has been cleared was taken picture, than at each segment separated and measured his length and large. After that each segment which has been separated observed used binocular microscope stereo $0,8 \mathrm{X}$ and taken the pictures. Then analyzed the pictures.

\section{RESULT AND DISCUSSION}

Based on observations that have been done, the result is:

Table 1. The length and large of vertebrae cervical of Egretta garzeta.

\begin{tabular}{lll}
\hline Segment & Length $(\mathbf{C m})$ & Large $(\mathbf{C m})$ \\
\hline $\mathrm{C} 1$ & 1,3 & 1,7 \\
$\mathrm{C} 2$ & 1,4 & 1,5 \\
$\mathrm{C} 3$ & 1,5 & 1,5 \\
$\mathrm{C} 4$ & 1,5 & 1,7 \\
$\mathrm{C} 5$ & 1,8 & 1,4 \\
$\mathrm{C} 6$ & 1,5 & 1,4 \\
$\mathrm{C} 7$ & 1,5 & 1,4 \\
$\mathrm{C} 8$ & 1,5 & 1,3 \\
$\mathrm{C} 9$ & 1,5 & 1,4 \\
$\mathrm{C} 10$ & 1,5 & 1,5 \\
$\mathrm{C} 11$ & 1,5 & 1,6 \\
$\mathrm{C} 12$ & 1,5 & 1,9 \\
$\mathrm{C} 13$ & 1,3 & 2,4 \\
\hline
\end{tabular}


The table above is measurement of the length and large of the Egret's segment. From this measurement it is know that the C5 segment looks more longer because the condyle position before the C5 segment is loced in the dorsal side while the condyle position after C5 setting is in the ventral so that the C5 position is the segment is tilted and looks broken.

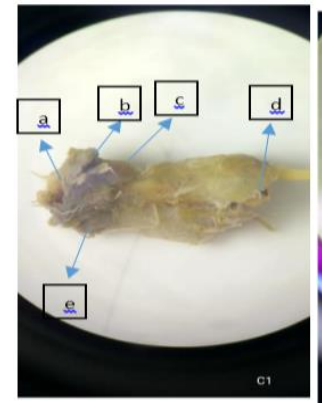

A

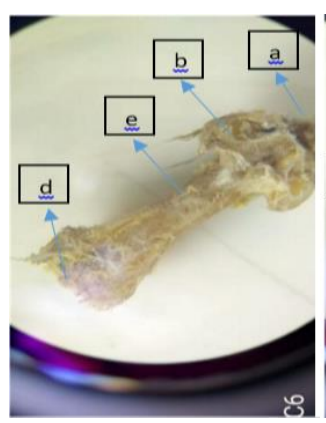

C

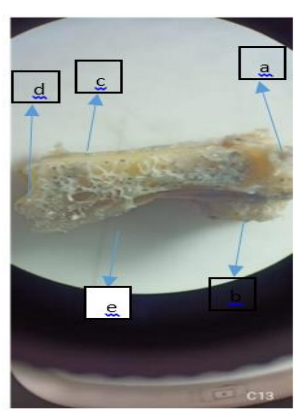

Figure 1. (Fig. A-E) Vertebrae cervical segment number 1, 5, 7, and 13 of Egretta. (a) anterior, (b) Condyle, (c) dorsal, (d) posterior, (e) Ventral

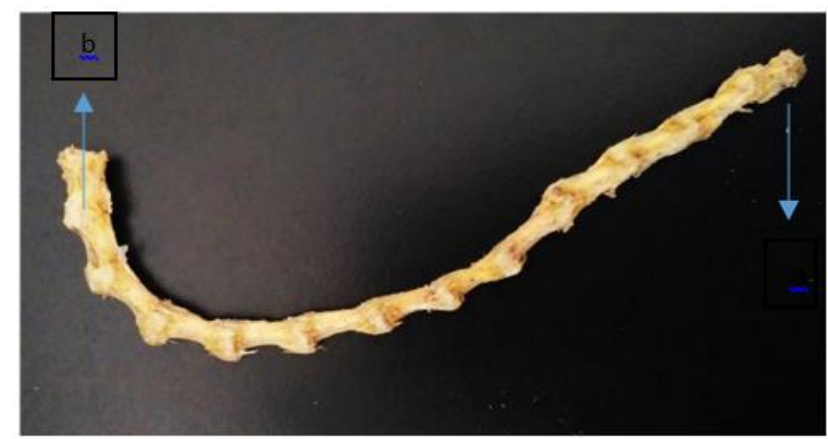

Figure 2. Picture of Egretta's Vertebrae Cervical from C1 to C13. (a) Anterior, (b) Posterior
We use the term cervical vertebrae to mean the true cervical (without ribs or with fused ribs). Neck length and neck posture are both relevant to give the appropriate position of the head during all kinds of behaviors. Size, morphology ad number of vertebrae are three important variables involved the motion of the neck. Egret's neck is composed of 13 vertebrae, each of which has a different structure and functions. In other extant bird, the number of cervical vertebrae ranges from 11 (some parrots) to 25 (swans) (Benoit, 1950). On Egret, in sections C5 to C7 have special characteristics. The sixth neck bone lengthens and the arrangement of muscle connections is elastic. The sixth vertebra in Egret's neck is longer than the others, and pivots forward around its attachment to the seventh neck vertebra. The functions of Pivot points is to unbalance the bird in the forward directions (thus discouranging dips to the rear). The ends of the pivot have downward protrusions that hit stops on the stand placed so that hit stops on the stand placed so that the bird is free to rock when in a vertical position, but cannot quite rotate enough ro be horizontal during a dip (Pfeiffer, 2015). Because of that when they catch prey, the neck can bend down until it reaches the ground surface. Egret catch prey with a Bill Stab, which is a downward or lateral strike involving fast, directed movement of the head and neck while the body remains still. This is the characteristic capture stroke of the long necked Egret, which have full development of specialized neck vertebrae, the elongated sixth cervical vertebra acting as a hinge for the forward strike. The neck craning is looking about with head and neck outstretched. Egretta also move their head and neck around to look more carefully for prey. When flying position, the neck can be folded to from the letter $\mathrm{S}$. The body's structure allows the Egret adapt to fly, the body's structure is strong enough to withstand the pressure when taking off, flying, and landing (Grzimek, 1972). This can occur because of the location of the condyle on different segment of vertebrae cervical from $\mathrm{C} 1$ to $\mathrm{C} 4$ on the ventral side, while on $\mathrm{C} 5$ to $\mathrm{C} 13$ the condyle is on the dorsal side. In addition, the presence of a pivot point on C6 allows the Egret's neck not to break due to vertebral elasticity.

\section{CONCLUSION}

Egret's neck is composed of 13 vertebrae, each of which has a different structure and functions. In sections C5 to C7 have special characteristics. The sixth neck bone lengthens and the arrangement of muscle connections is elastic. Then in C6 there is a pivot point that allows the Egretta to pull their necks into an $\mathrm{S}$ shape and allows Egret to push the head forward and catch prey at high speed. The functions of Pivot points is to unbalance the bird in the forward directions (thus discouranging dips to the rear). The ends of the pivot have downward 
protrusions that hit stops on the stand placed so that hit stops on the stand placed so that the bird is free to rock when in a vertical position, but cannot quite rotate enough ro be horizontal during a dip.

\section{REFERENCES}

Benoit, J, Berlioz J, Bourlier F, Grasse PP, Letard E, Matthey R, Mayaud N, Oehmichen E,

Pasteels J, Piveteau J. 1950. Traite de Zoologie, Anotomie, Systematique, Biologie. Paris: Tome XV Oiseaux. Masson et Cie Editeur
Grzimek, ed. Bernhard. 1972. Grzimek's Animal Life Encyclopedia Vol 7 Birds I. New York: Van Nostrand

Hancock, J and J. A. Kushlan. 1984. The Herons Handbook. New York: Harper and Row

MacKinnon, J., K. Philips and B. Van Balen. 2010. BururngBurung di Sumatera, Jawa, Bali dan Kalimantan. Bogor: Puslitbang Biologi LIPI

Pfeiffer, Friedrich. 2015. Introduction to Dynamics. Germany: Institute of Applied Mechanics

Wheler, Alwyne and Andrew K.G Jones. 1929. Fish. New York: Cambridge University Press 
THIS PAGE INTENTIONALLY LEFT BLANK 